\title{
Holoplankton, meroplankton, and meiofauna associated with marine snow
}

\author{
Alan L. Shanks ${ }^{1, *}$, Keith Walters ${ }^{2}$ \\ ${ }^{1}$ Oregon Institute of Marine Biology, University of Oregon, PO Box 5389, Charleston, Oregon 97420, USA \\ ${ }^{2}$ Department of Biology, PO Box 60, Middle Tennessee State University, Murireesboro, Tennessee 37132, USA
}

\begin{abstract}
The associations of holoplankton, meroplankton and meiofauna with marine snow, as well as their behavior upon encountering marne snow, were investigated using SCUBA in the field and a vertical flume in the laboratory. Field samples were collected in the Atlantic Ocean off Charleston, South Carolina, USA. ( 3 dates) and in the Pacific Ocean at 2 locations in the San Juan Islands, Washington, USA (7 dates). Aggregates were present and abundant on all days (range 1 to 63 aggregates $~^{-1}$ ) but constituted a small percentage of the water column by volume (avg $0.078 \%$ ). Holoplanktonic adult calunoid and cyclopoid copepods, larvaceans, and copepod nauplii were found on aggregates. On average $<1 \%$ of the calanoid and cyclopoid copepods sampled were on aggregates, indicating a weak association with marine snow. In contrast, on average $2.6 \%$ of the larvaceans and $4.8 \%$ of the copepod nauplii sampled resided on aggregates, where they were, respectively, 33 to 62 times more concentrated on marne snow compared to the surrounding water. Percentages of harpacticoid copepods, nematodes, and foraminiferans on aggregates were $12.4,69.9$ and $47.2 \%$, respectively, and all were significantly concentrated on aggregates. Cyprids, bryozoan cyphonautes, and larval echinoderms were either weakly associated with or not found on aggregates. In contrast, bivalve and gastropod veligers and larval anthozoans were significantly concentrated on marine snow, with $5.8,9.4$, and $13.5 \%$, respectively, found on aggregates. Observations in a vertical flume indicated that upon contacting marine snow calanoid and cyclopoid copepods swam away, copepod nauplii swam inside aggregates for several minutes before swimming off, and nematodes were observed to remain in aggregates throughout the observation period adding material from the surrounding water to the 'home' aggregate. These observations suggest that plankters and meiofauna in the water column may spend several hours $\mathrm{d}^{-1}$ visiting or residing on aggregates, and may visit from 10 s to 100 s of aggregates $\mathrm{d}^{-1}$. The concentration and behavior of organisms on aggregates suggests that marine snow is an important component of the pelagic environment for a variety of both holoplanktonic and meroplanktonic zooplankton.
\end{abstract}

KEY WORDS: Marine snow Aggregates - Naupliı - Meroplankton - Veligers Holoplankton - Copepod Nematode Meiofauna

\section{INTRODUCTION}

Marine snow is a ubiquitous feature of pelagic environments. It has been found in near-shore surface waters and in the open ocean, at great depths, in estuaries, and most recently in lakes (Alldredge \& Silver 1988, Grossart \& Simon 1993). Marine snow abundances range from $<1$ aggregate $\mathrm{l}^{-1}$ in the deep sea and oligotrophic surface waters to $100 \mathrm{~s} \mathrm{I}^{-1}$ in estuaries

·E-mail: ashanks@oimb.uoregon.edu
(Alldredge \& Silver 1988). Numerous studies have found that marine snow (also known as aggregates) sinks and constitutes much of the vertical flux of material through the water (Shanks \& Trent 1980, Asper 1986, Alldredge \& Gotschalk 1988, Riemann 1989, Walsh \& Gardner 1992, Syvitski et al. 1995). Most marine snow is composed of aggregations of detritus, microbes, and phytoplankton embedded in or held together by a mucous matrix (Alldredge \& Silver 1988). Concentrations of microbes and phytoplankton are frequently orders of magnitude greater in aggregates 
than in the aggregate-free surrounding waters (Silver et al. 1978, Alldredge \& Youngbluth 1985, Beers et al. 1986, Caron et al. 1986, Davoll \& Silver 1986, Lochte \& Turley 1988, Simon et al. 1990)

The importance of marine snow to zooplankton (holoplankton or meroplankton) will depend on both the frequency with which plankters encounter aggregates and the plankter's behavior following contact. The abundances of aggregates, from $100 \mathrm{~s}$ to $100000 \mathrm{~s}$ $\mathrm{m}^{-3}$, suggest a significantly high probability of zooplankton-aggregate encounters. Once an aggregate is encountered a zooplankter may simply bounce off the aggregate or it may enter and exploit the aggregate habitat. High microbial densities on aggregates compared to the surrounding seawater suggest that associating with marine snow may be advantageous nutritionally for those zooplankton which feed on microbes.

The first observations of zooplankton-aggregate associations were made by Alldredge $(1972,1976)$. She found that some types of crustaceans visit and feed on microbes trapped on the mesh of abandoned larvacean houses, one source of marine snow. Several more recent papers (Shanks \& Edmondson 1990, Bochdansky \& Herndl 1992, Green \& Dagg 1997) also found that some types of holoplanktonic crustaceans visit aggregates and a number of meiofauna and meroplankton were concentrated on aggregates. Meiofaunal copepods that encounter aggregates also significantly affect the physical and biological aspects of aggregates (Walters \& Shanks 1996). Apparently a variety of zooplankters may inhabit or visit marine snow. The purpose of the present study was to expand upon previous observations by (1) collecting a greater temporal and geographical range of samples to determine the variation in zooplankton-aggregate association, and (2) examining the behavior of zooplankton that encounter aggregates.

\section{METHODS}

Field sampling. Field sampling of marine snow took place in the waters of the Atlantic and the Pacific oceans. Samples were collected on 3 dates in 1991 in the Atlantic Ocean near Charleston, South Carolina, USA approximately $3 \mathrm{~km}$ offshore $\left(32^{\circ} 43^{\prime} \mathrm{N}, 79^{\circ}\right.$ $43^{\prime}$ W). In the Pacific Ocean samples were collected on 5 dates in July and August 1992 in Parks Bay, Shaw Island $\left(48^{\circ} 33^{\prime} \mathrm{N}, 122^{\circ} 59^{\prime} \mathrm{W}\right)$, and on 2 dates in August 1992 in West Sound, Orcas Island $\left(48^{\circ} 37^{\prime} \mathrm{N}, 122^{\circ}\right.$ $58^{\prime} \mathrm{W}$ ). Shaw and Orcas Islands are located in the San Juan Islands, Washington, USA.

At all of the sampling sites and on all dates 4 to 8 replicate marine snow samples containing 30 to 200 aggregates $>1 \mathrm{~mm}$ in longest dimension were col- lected from between 3 and $5 \mathrm{~m}$ depth by SCUBA divers using the techniques of Shanks \& Edmondson (1990). Aggregates were drawn into a $1 \mathrm{ml}$ sampling syringe and transferred via a connected T-valve into a $50 \mathrm{ml}$ reservoir syringe. With this sampling technique 100 aggregates can be concentrated in $<25 \mathrm{ml}$ of water To aid in the visualization of the aggregates the sampling syringe was mounted on a frame with an underwater flashlight. The beam from the flashlight illuminated the water in front of the intake for the sample syringe. Light reflected off aggregates enabled divers to see even the clear mucous matrix of the marine snow. The divers swam to the up-current end of their tether and sampled as the current carried them to the downstream end of their tether. Sampling was haphazard; the divers sampled aggregates in sequence as they passed through the beam of the flashlight. On 20 August 1992 divers visually identified 2 size classes of aggregates and collected separate replicate samples of 'small' (1 to $10 \mathrm{~cm}$ long; 100 aggregates sample ${ }^{-1}$ ) and 'large' (>10 cm long; 30 aggregates sample ${ }^{-1}$ ) aggregates.

Plankton samples (i.e. marine snow and the water surrounding marine snow) were collected in the Atlantic Ocean using a submersible bilge pump. A 37.51 volume of water was pumped from the depth at which the marine snow was sampled and filtered through a $53 \mu \mathrm{m}$ mesh plankton net. In the San Juan Islands plankton samples were collected with a $25 \mathrm{~cm}$ diameter $53 \mu \mathrm{m}$ mesh plankton net equipped with a flow meter The net was towed vertically from $6 \mathrm{~m}$ to the surface (approximately $300 \mathrm{I}$ filtered). All samples were stained with Rose Bengal and preserved in $3 \%$ Formalin

The size and concentration of marine snow was determined using the photographic technique developed by Honjo et al. (1984). Up to 30 photographs of a $13.2 \times 9.2 \times 5 \mathrm{~cm}$ volume of water $(0.6071)$ were taken at depths between 3 and $5 \mathrm{~m}$. Photographs were taken at random using the following procedure: divers adjusted their buoyancy to become neutrally buoyant, closed their eyes, drifted with the current for $15 \mathrm{~s}$ (the time needed to recharge the strobes), and then took a photograph. The process was repeated until the entire role of film had been exposed.

Sample analysis. Photographs were projected (11.5x the image size) onto a digitizing pad and the dimensions of all aggregates greater than $1 \mathrm{~mm}$ (the size of the smallest aggregates collected by divers) were determined. The volume of the more spherical aggregates was calculated from the diameter assuming a spherical shape. The volume of long aggregates was calculated from long and short axes measurements assuming a cylindrical shape. In each photograph the number of aggregates $>1 \mathrm{~mm}$ in any dimension was 
determined and used to calculate the concentration of aggregates (i.e. no. $\mathrm{l}^{-1}$ ).

Organisms in marine snow and plankton samples were enumerated at $400 \times$ under white light using a compound microscope. The entire aggregate sample was enumerated. The pump and plankton net samples were sub-sampled prior to microscopic examination using a Stempel pipette (Omori \& Ikeda 1984). Samples or sub-samples were placed in $15 \mathrm{ml}$ centrifuge tubes and spun for $5 \mathrm{~min}$ on a hand-crank centrifuge. Sedimented animals were removed from the tube with a Pasteur pipette and placed in a Sedgwick Rafter cell. Copepods, copepod nauplii, larvaceans, nematodes, foraminiferans, bivalve veligers, gastropod veligers, larval anthozoans, larval bryozoans, barnacle cyprids and larval polychaetes were enumerated in the marine snow and plankton samples. The results of the analysis of larval polychaetes on aggregates have been reported in a separate paper (Shanks \& del Carmen 1997).

The number of organisms aggregate ${ }^{-1}$ and the number of aggregates $\mathrm{l}^{-1}$ (see Table 1) enabled calculation of the number of organisms $1^{-1}$ on aggregates. Faunal concentrations in the water surrounding aggregates were determined by subtracting the concentration of organisms on aggregates from the total concentration as determined from the plankton tows or pump samples. The percentage of the organisms in the water column that were on aggregates were determined using these values.

Differences in faunal concentrations on and off aggregates were analyzed by nested ANOVAs applied to appropriately transformed data. Aggregate and water column sub-samples were nested within dates for each of the 3 locations to test for date and aggregate effects on faunal concentrations in the water column. All tests were run using SAS 6.11 for PC and GLM statistical routine (Joyner 1985).

Behavioral observations. Observations of zooplankton responses to marine snow were made in a vertical flume that was designed to suspend aggregates so that observations could be made through a dissecting microscope. The vertical flume consisted of a Plexiglas tank $7 \times 15 \times 5 \mathrm{~cm}$. Water entered the tank from the bottom and passed through a baffle before entering the working section of the flume. Water exited at the top of the tank through a ring of tiny holes. An adjustable peristaltic pump was used to circulate the water through the tank. A surge damper, which removed most of the surging motion of the flow generated by the peristaltic pump, was placed between the pump and the tank intake.

Observations were made with a dissecting microscope mounted horizontally in front of the tank. The flume was mounted on a scissors jack which allowed the adjustment of the vertical position of objects in the tank relative to the microscope. The side to side positioning and focusing of the microscope was achieved by mounting the microscope on a pair of linear motion ball bearing slides. The linear motion slides were mounted perpendicular to each other thus allowing the smooth side to side motion and focusing of the microscope. Lighting was provided by a fiber optic lamp with a red filter over the output lens. With this system an aggregate and associated animals could be observed for many minutes through the dissecting microscope.

Plankton collected with a $53 \mu \mathrm{m}$ plankton net were placed in the vertical flume along with aggregates made in the laboratory on a roller table (Shanks \& Edmondson 1989). Aggregates were no more than $24 \mathrm{~h}$ old and were transferred from the roller table tanks to the vertical flume with a wide bore $(1 \mathrm{~cm})$ pipette. An aggregate was selected from those present in the middle of the vertical flume, and this aggregate was observed for as long as possible (up to $15 \mathrm{~min}$ ). Aggregates would eventually migrate sideways across the tank until they entered the boundary layer next to one of the side walls, at which point they would sink to the bottom of the tank in the reduced flow field of the boundary layer. While an aggregate was under observation all of the responses of organisms contacting the aggregate were noted. Approximately $12 \mathrm{~h}$ of observations were conducted during this study.

\section{RESULTS}

\section{Field samples}

Marine snow was present on all of the sampling dates (Table 1). Aggregates tended to be smaller and more abundant at the stations off Charleston, South Carolina. Here aggregate lengths were approximately 1 to $2 \mathrm{~mm}$ and concentrations ranged from 14 to $63 \mathrm{l}^{-1}$. Aggregates were larger and less numerous at the sampling sites in the Pacific Ocean. In Parks Bay aggregates ranged in length from $>1$ to $6 \mathrm{~mm}$ and in concentration from 3 to $11 \mathrm{l}^{-1}$. The largest aggregates were found in West Sound. They ranged in length from 90 to $171 \mathrm{~mm}$ and in concentration from 0.1 to $2 \mathrm{l}^{-1}$ Although aggregates were present everywhere and often abundant, they occupied only a tiny portion of the water column (Table 1). At most, aggregates occupied only $0.5 \%$ of the water by volume (small plus large aggregates on 20 August 1992, Table 1). On average aggregates occupied only $0.078 \%$ of the water by volume.

Zooplankton were present on aggregates on all of the sampling dates (Table 2). At the Atlantic sampling 
Table 1. Mean (SD), length, diameter, volume and no. $\mathrm{l}^{-1}$ of marine snow photographed in the Atlantic and Paclfic Oceans. $\mathrm{n}=$ number of photographs inspected. Total aggregates are the total number of aggregates measured. \% Water volume is the percentage of the water volume photographed made up of aggregates

\begin{tabular}{|c|c|c|c|c|c|c|c|}
\hline Date & $\mathrm{n}$ & $\begin{array}{c}\text { Total } \\
\text { aggregates }\end{array}$ & $\begin{array}{l}\text { Length } \\
\text { (mm) }\end{array}$ & $\begin{array}{l}\text { Diameter } \\
(\mathrm{mm})\end{array}$ & $\begin{array}{l}\text { Volume } \\
\text { (ml) }\end{array}$ & Aggregates $\mathrm{I}^{-1}$ & $\begin{array}{l}\% \text { Water } \\
\text { volume }\end{array}$ \\
\hline \multicolumn{8}{|l|}{ Atlantic, Charleston } \\
\hline 30 Aug 1991 & 8 & 289 & $2.01(2.38)$ & $0.58(0.55)$ & $0.0013\{0.0058\}$ & $62.82(48.29)$ & 0.008 \\
\hline 4 Oct 1991 & 5 & 50 & $1.68\{1.34\}$ & $0.50(0.28)$ & $0.0004(0.004)$ & $13.48(9.98)$ & 0.006 \\
\hline 1 Nov 1991 & 12 & 387 & $1.55(1.47)$ & $0.60(0.33)$ & $0.0007(0.0018)$ & $53.13(19.66)$ & 0.004 \\
\hline \multicolumn{8}{|l|}{ Pacific, Parks Bay } \\
\hline $22 \mathrm{Jul} 1992$ & 22 & 20 & $5.18(8.79)$ & $0.72(0.77)$ & $0.0181(0.613)$ & $4.70(1.81)$ & 0.009 \\
\hline 28 Jul 1992 & 28 & 28 & $2.26(1.98)$ & $0.44(0.17)$ & $0.0005(0.0009)$ & $8.71(4.01)$ & 0.0004 \\
\hline 31 Jul 1992 & 9 & 67 & $1.43(0.92)$ & $0.82(0.22)$ & $0.0009(0.0009)$ & $11.04(4.66)$ & 0.001 \\
\hline 3 Aug 1992 & 16 & 35 & $3.81(5.84)$ & $1.22(0.84)$ & $0.0120(0.0265)$ & $3.29(2.55)$ & 0.004 \\
\hline 6 Aug 1992 & 29 & 65 & $6.15(10.78)$ & $0.96(0.56)$ & $0.0112(0.382)$ & $3.29(2.77)$ & 0.004 \\
\hline \multicolumn{8}{|l|}{ Pacific, West Sound } \\
\hline 20 Aug 1992, small & 28 & 23 & $55.46(68.28)$ & $5.27(6.57)$ & $1.295(3.772)$ & $1.01(1.08)$ & 0.131 \\
\hline 20 Aug 1992, large & 28 & 4 & $156.75(20.15)$ & $17.10(0.00)$ & $35.981(4.626)$ & $0.11(0.44)$ & 0.396 \\
\hline 27 Aug 1992 & 28 & 44 & $51.60(58.37)$ & $3.22(2.94)$ & $1.135(4.084)$ & $2.14(1.68)$ & 0.243 \\
\hline Over all dates & & & & & & & $\begin{array}{c}0.078 \\
\{0.158, n=10\}\end{array}$ \\
\hline
\end{tabular}

sites there were approximately 0.3 zooplankters aggregate $^{-1}$. Zooplankton were less abundant on the aggregates sampled in Parks Bay where there were approximately 0.1 individuals on each aggregate. The larger aggregates sampled in West Sound were more populated by zooplankters. Here there were between 0.3 zooplankters aggregate ${ }^{-1}$ (small aggregates, 20 August 1992) and 1.7 zooplankters aggregate ${ }^{-1}$ (large aggregates, 20 August 1992). Averaged over all sam-

Table 2. Numbers of organisms on aggregates at each sampling site. Enumerated animals included copepods, copepod nauplii, larvaceans, nematodes, foraminiferans, bivalve veligers, gastropod veligers, larval anthozoans, larval echinoderms, cyprids and larval bryozoans. $n=n o$. of replicates

\begin{tabular}{|c|c|c|}
\hline Date & Mean (SD) & $n$ \\
\hline \multicolumn{3}{|l|}{ Atlantic, Charleston } \\
\hline 30 Aug 1991 & $0.45(0.36)$ & 4 \\
\hline 4 Oct 1991 & $0.17(0.05)$ & 4 \\
\hline 1 Nov 1991 & $0.34(0.08)$ & 8 \\
\hline \multicolumn{3}{|l|}{ Pacific, Parks Bay } \\
\hline 22 Jul 1992 & $0.17(0.04)$ & 7 \\
\hline 28 Jul 1992 & $0.05(0.03)$ & 5 \\
\hline 31 Jul 1992 & $0.03(0.01)$ & 4 \\
\hline 3 Aug 1992 & $0.06(0.03)$ & 4 \\
\hline 6 Aug 1992 & $0.07(0.03)$ & 5 \\
\hline \multicolumn{3}{|l|}{ Pacific, West Sound } \\
\hline 20 Aug 1992, small & $0.33(0.08)$ & 4 \\
\hline 20 Aug 1992, large & $1.70(0.05)$ & 4 \\
\hline 27 Aug 1992 & $0.86(0.25)$ & 6 \\
\hline Avg over all dates & $0.38(0.50)$ & 11 \\
\hline
\end{tabular}

ple dates, zooplankton abundance on aggregates was approximately 0.38 individuals aggregate ${ }^{-1}$ (Table 2).

Larvaceans were absent from the samples collected in the Atlantic Ocean, but were present at all of the Pacific Ocean sampling sites. On all of the dates when larvaceans were present in the plankton (Table 3), they were also present in the marine snow samples. Larvaceans were more concentrated on aggregates in Parks Bay (Table 3) than in the surrounding water, but were not significantly more concentrated on aggregates in West Sound (Table 3). In Parks Bay and West Sound 2.9 and $1.7 \%$ of the larvaceans, respectively, were associated with aggregates (Fig. 1). If larvaceans were randomly distributed in the water column then one would expect the percentage of the population caught on aggregates to be similar to the percentage of the water volume occupied by aggregates (avg $0.078 \%$, Table 1) The average percentage of the larvaceans on aggregates was about $30 \times$ greater than the average percentage of the water occupied by marine snow.

Calanoid and cyclopoid copepods were present on all sample dates, and some copepods were associated with aggregates, on all but 1 date ( 31 July 1992). Copepods appeared to be associated weakly with aggregates with only $0.4 \%$ of the population on average associated with marine snow (Fig. 1), and no significant differences between aggregate and surrounding water concentrations were found on any date or at any sampling site (Table 3).

On all sampling dates, copepod nauplii were present in the plankton samples and on aggregates (Fig. 1). 
Table 3. Results of nested ANOVA on the log-transformed abundance data. To test for date and aggregate effects on faunal concentrations in the water column aggregate and water column, zooplankton samples were nested within sampling dates for each of the 3 sampling locations. There were no significant date effects. ns: no significant difference in concentration. None present: none of this particular organism was present in the water column at the time the samples were taken. More: of this particular organism on aggregates than in the water column. F-value shown in parentheses; ${ }^{\prime} p<0.05 ;{ }^{\prime} p<0.01 ; \cdots p<0.001 ; \cdots p<0.00001$

\begin{tabular}{|c|c|c|c|}
\hline & Atlantic $\left(F_{3,27}\right)$ & Parks Bay $\left(F_{5,39}\right)$ & West Sound $\left(F_{2,19}\right)$ \\
\hline Larvaceans & None present & More $\cdots \quad(5.22)$ & ns \\
\hline Calanoid/cyclopoid copepods & ns & ns & ns \\
\hline Nauplii & More $\cdots(867)$ & More $\cdots(28.22)$ & More ${ }^{\cdots *}(12.10)$ \\
\hline Harpacticoids & More $\cdots(21.78)$ & ns & ns \\
\hline Nematodes & ns & 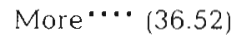 & More ${ }^{*} \quad$ (5.09) \\
\hline Foraminiferans & More $\cdots(23.92)$ & None present & None present \\
\hline Bivalves veligers & More $\cdots(8.38)$ & More $\cdots(5.00)$ & More $\cdots(14.17)$ \\
\hline Gastropod veligers & ns & ns & More ${ }^{\prime \prime} \quad(8.34)$ \\
\hline Larval anthozoans & None present & ns & More $\cdots(113)$ \\
\hline
\end{tabular}

Further, at all of the sample sites naupliar concentrations were significantly higher on aggregates than in the surrounding water (Table 3 ). On average, over all of the study sites, $4.75 \%$ of the copepod nauplii were caught on marine snow and this association with aggregates ranged from 1.0 to $11.1 \%$ of the population (Fig. 1). Comparing these percentages to the percentage of the water occupied by aggregates suggests that copepod nauplii were on average $60 \times$ more concentrated on aggregates than they were in the water surrounding the aggregates and that this concentration factor ranged from as little as $3 \times$ on 20 August 1992 to as high as nearly $5000 \times$ on 1 November 1991 .

Harpacticoid copepods were present in the plankton samples on all of the sampling dates (Fig 2). They were absent from marine snow samples collected in the Atlantic Ocean on 4 October 1991 and from the Parks Bay aggregate samples collected on 31 July 1992 and 3 August 1992. The percentage of the population associated with aggregates at the Atlantic, Parks Bay, and West Sound sampling sites were $54.7,1.6$ and $6.7 \%$, respectively (Fig. 2). Only in the Atlantic samples were harpacticoid copepods significantly more concentrated on the aggregates than in the surrounding water (Table 3 ), on average $700 \times$ more concentrated.

Nematodes were rare components of the plankton, with concentrations gen-
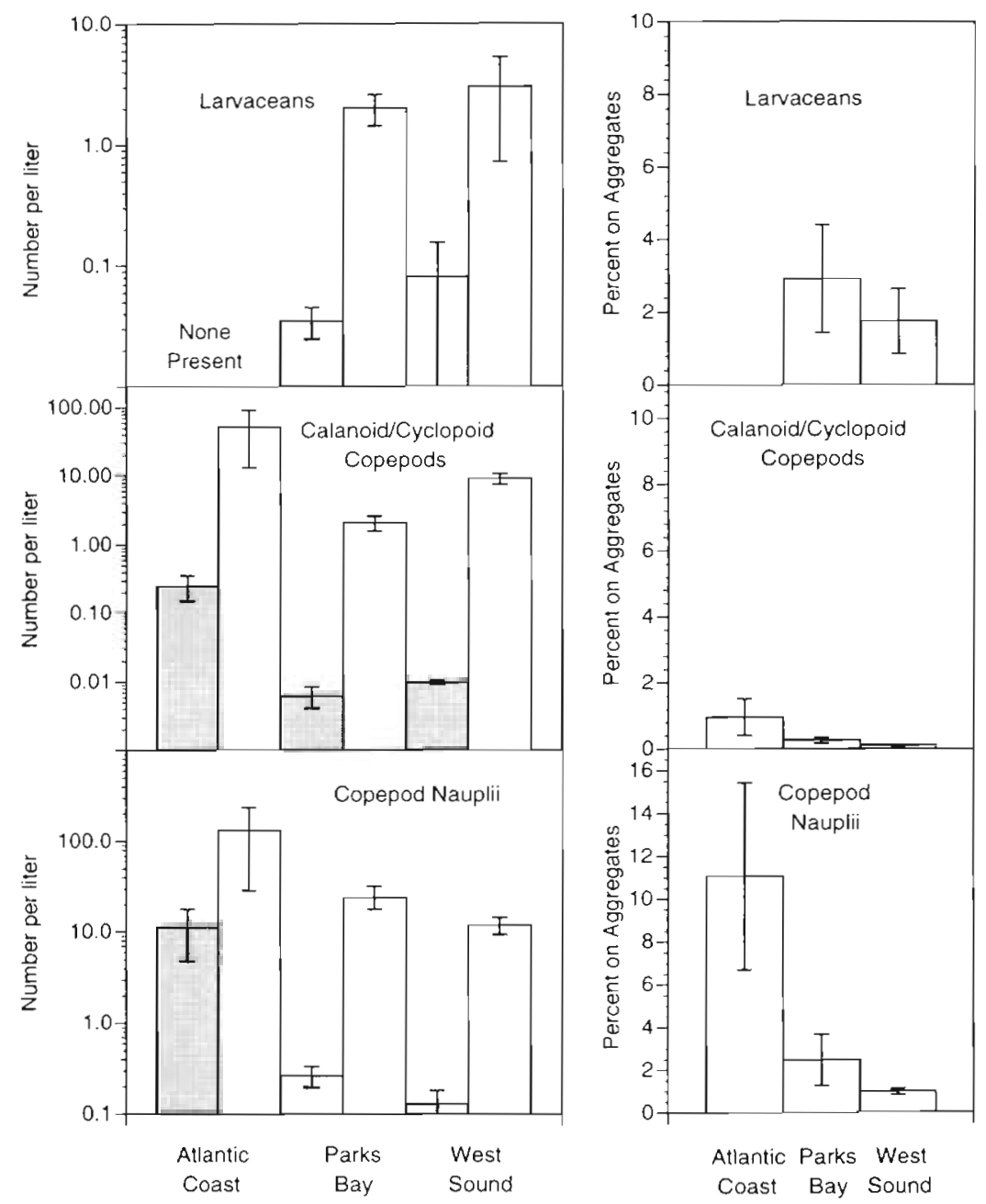

Fig. 1. Holoplankton on marine snow. Left hand graphs present a comparison of the mean numbers $( \pm \mathrm{SE}$ ) of selected holoplankters per liter of water which were on aggregates (gray bars) and in the aggregate-free surrounding water (clear bars) at the 3 sampling sites. Note that the vertical axis is a log scale. Right hand graphs present the mean percentages $( \pm S E)$ of the selected holoplankters on aggregates at the 3 sampling sites 

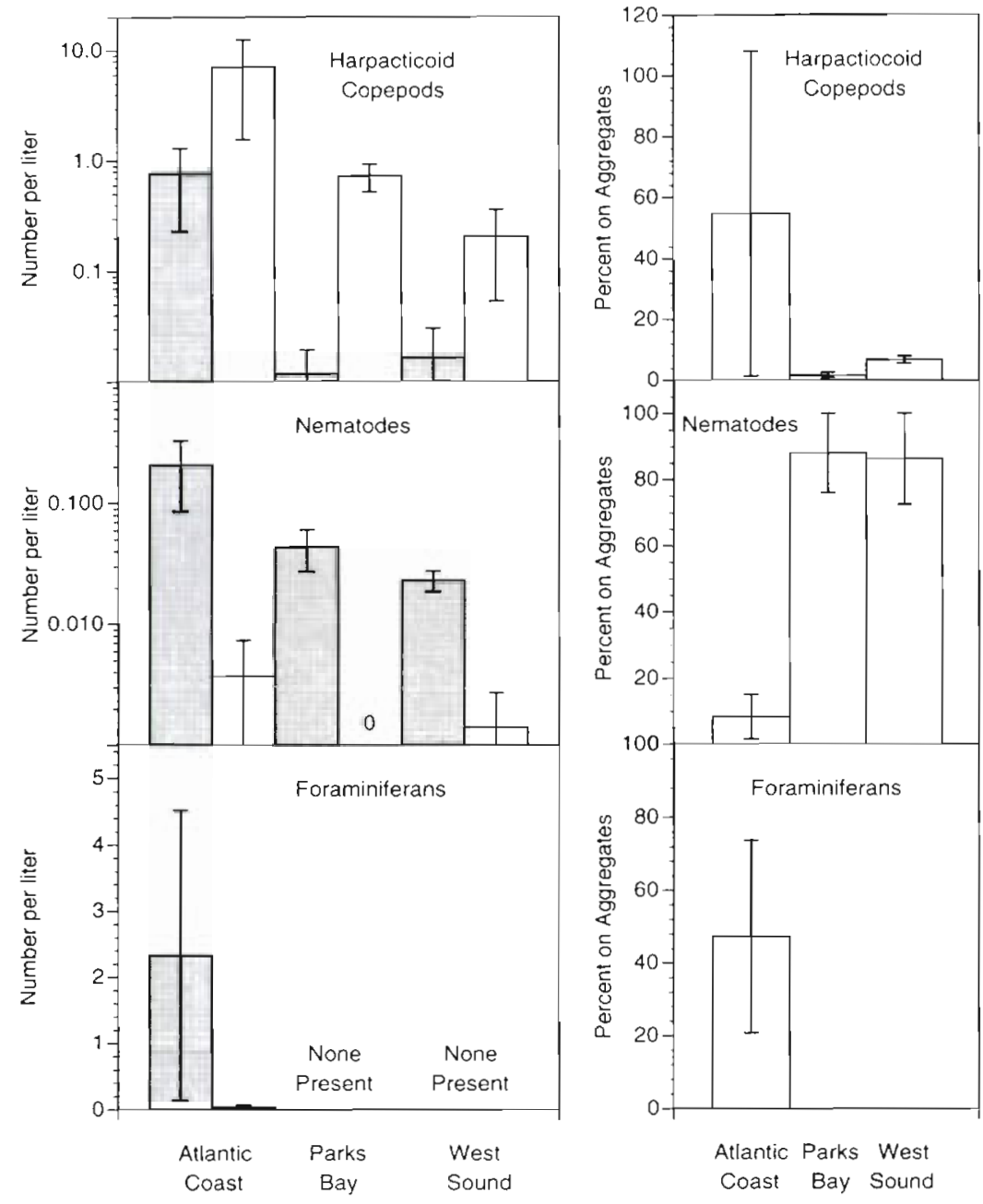

Fig. 2. Meiofauna on marine snow. Left hand graphs present a comparison of the numbers $( \pm \mathrm{SE})$ of selected meiofauna per liter of water which were on aggregates (gray bars) and in the aggregate-free surrounding water (clear bars) at the 3 sampling sites. Note that the vertical axis is a log scale. Right hand graphs present the mean percentages ( $\pm \mathrm{SE}$ ) of the selected meiofauna on aggregates at the 3 sampling sites

erally less than $100 \mathrm{~m}^{-3}$, they were, however, present in the plankton samples on 9 of the 10 sampling dates (absent on 3 August 1992). Nematodes were significantly and highly concentrated on the aggregates sampled at Parks Bay and West Sound (Table 3), but they were not significantly concentrated on the aggregates sampled in the Atlantic Ocean. Only $8.3 \%$ of the nematodes sampled were found on the aggregates at the Atlantic sample site while at the Parks Bay and West Sound sites 88 and $86 \%$ of the nematodes sampled, respectively, were associated with aggregates (Table 3). At the Pacific sample sites nematodes were around $1000 \times$ more concentrated on aggregates than in the water surrounding aggregates.

Foraminiferans (most were spiral in form) were only present in the plankton samples collected in the
Atlantic Ocean off Charleston, South Carolina (Fig. 2). They were significantly and highly concentrated on aggregates at this sampling site (Table 3 ). On average, $47.2 \%$ of the foraminiferans collected were associated with aggregates. This degree of association suggests that they were approximately $600 \times$ more concentrated on aggregates than in the surrounding aggregate-free waters.

On all sampling dates bivalve veligers were present in the plankton samples and they were significantly and highly concentrated on the sampled aggregates (Table 3 ). The percentage of the bivalve veligers on aggregates in the Atlantic, Parks Bay, and West Sound samples was 5.5, 4.3, and $9.8 \%$, respectively (Fig. 3 ). These percentages suggest that at these sample sites bivalve veligers were from 50 to $>100 \times$ more concentrated on aggregates than in the surrounding water.

Gastropod veligers were only present in aggregates on half of the sampling dates and they were only significantly concentrated on aggregates in West Sound (Table 3). In West Sound $33.5 \%$ of the gastropod veligers sampled were on aggregates (Fig. 3) which suggests that they were $>400 x$ more concentrated on aggregates than in the surrounding waters. In the Atlantic Ocean and Parks Bay samples, 5.6 and $2.1 \%$ of the gastropod veligers, respectively, were associated with. aggregates (Fig. 3).

Larval anthozoans, both planula and later stage larvae with developing tentacles, were observed on 5 of the 7 sampling dates in the Pacific Ocean. The larvae were similar in appearance to Ceriantharian larvae (Hyman 1940, LeLoup 1962). These larvae were rare in Parks Bay, with concentrations $<50 \mathrm{~m}^{-3}$. They were more numerous in West Sound where concentrations ranged from approximately 80 to $>2500 \mathrm{~m}^{-3}$. On $2 \mathrm{sam}$ ple dates in Parks Bay (22 July 1992 and 3 August 1992), when anthozoan larvae were at low concentrations, none were present on aggregates, and on the other sampling dates their concentration on aggregates was not significantly different from that in the surrounding water (Table 3). In West Sound, however, they were significantly and highly concentrated on the marine snow (Table 3), with on average $31.6 \%$ on aggregates. 

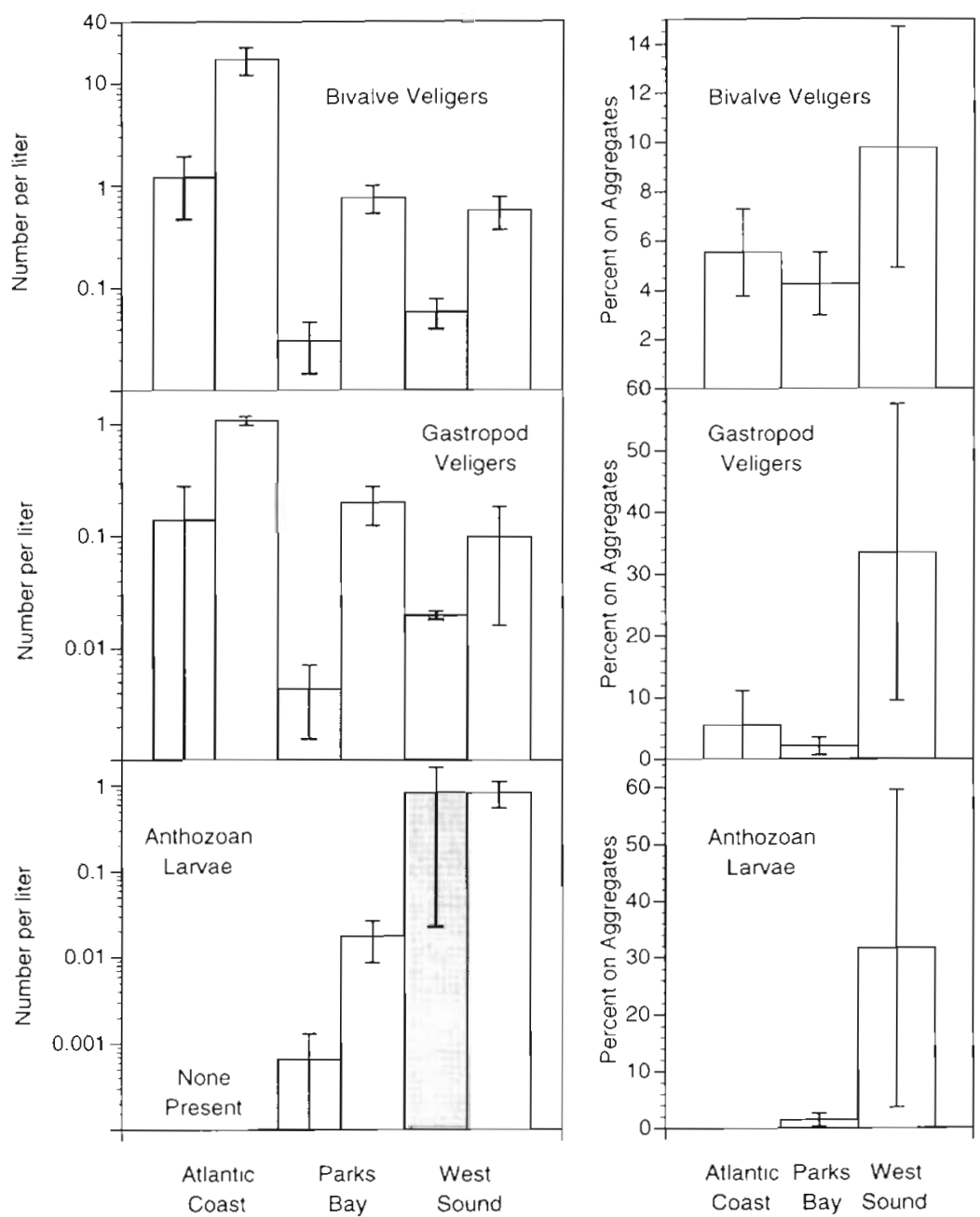

Fig. 3. Meroplankton on marine snow. Left hand graphs present a comparison of the mean numbers $( \pm S E)$ of selected meroplankters per liter of water which were on aggregates (gray bars) and in the aggregate-free surrounding water (clear bars) at the 3 sampling sites. Note that the vertical axis is a log scale. The right hand graphs present the mean percentages ( $\pm \mathrm{SE}$ ) of the selected meroplankters on aggregates at the 3 sampling sites

Barnacle cyprids and bryozoan cyphonautes were never found to be associated with aggregates. Larval echinoderms were weakly associated with aggregates on 2 dates, 30 November 1991 and 6 August 1992. when 3.62 and $0.66 \%$ of the echinoderms, respectively, were on aggregates. They were not present on aggregates on any other sample dates.

\section{Behavioral observations}

The behavior of metazoans (e.g. larval polychaetes, copepods, nematodes, and copepod nauplii) upon contacting marine snow was monitored during $12 \mathrm{~h}$ of observations using the vertical flume. Observations on the association of larval polychaetes with aggregates are reported in a separate paper (Shanks \& del Carmen 1997). The behavior of calanoid copepods upon contacting marine snow was observed on 5 occasions. In each case the behavior was the same; the individual simply bumped into the aggregate and then swam away. In contrast, the 1 harpacticoid copepod observed contacting marine snow briefly crawled about on the surface of the aggregate and then swam adjacent to the aggregate for several minutes before the aggregate was lost from view. Nematodes were observed on 4 occasions. In 3 cases the nematodes were on the aggregate at the time of observation and in the fourth case the nematode was free in the water and crawled into the aggregate upon contacting it. The behavior of the nematodes when on aggregates was the same. Nematodes crawled about within the aggregate and would repeatedly crawl to the edge of the aggregate extending at least half a body length out into the surrounding water. The extended portion of the body thrashed about violently. On several occasions the thrashing portion of the nematode contacted other aggregates in the surrounding water. In each case the individual curled around the 'free' aggregate and pulled it into the aggregate upon which it was residing. The added material became incorporated into the nematode's resident aggregate. In 3 of the 4 observations, the nematodes remained on the aggregate throughout the entire period of observation ( 3 to $10 \mathrm{~min}$ ). During 1 thrashing event the individual lost contact with the aggregate. Nematodes did not appear to leave the aggregates voluntarily. Copepod nauplii were observed associated with aggregates on 5 occasions. Either they were observed to swim close to an aggregates (i.e. $<1$ body length away) with the posterior end of the animal oriented toward the aggregate surface (this orientation was maintained despite the flow of water past the suspended aggregate) or they were observed to enter the aggregate matrix and swim about within the interior of the aggregate. Copepod nauplii tended to associate with an aggregate for several minutes and then to swim away.

In summary: (1) Metazoans which were observed to associate with aggregates were not passively entan- 
gled in aggregates, rather the association was due to the activity of the organism. (2) Some zooplankters (e.g. calanoid copepods) were not observed to associate with aggregates. (3) Some metazoans (e.g. copepod nauplii and, perhaps, harpacticoid copepods) appeared to visit aggregates, remaining for several minutes and then swimming away. (4) Other metazoans (e.g. nematodes) appeared to reside on aggregates and even to add to the size of the 'home' aggregate by the collection of material from the surrounding water.

\section{DISCUSSION}

Marine snow was present on all of the sampling dates and on all of these dates metazoans were concentrated on aggregates. Overall, there was more than 1 metazoan per every 3 aggregates (Table 2). Of the enumerated zooplankters, some were associated only very weakly or not at all with aggregates (e.g. cyprids, larval bryozoans, larval echinoderms and calanoid and cyclopoid copepods). All of the remaining enumerated organisms (e.g. larvaceans, copepod nauplii., harpacticoid copepods, nematodes, foraminiferans, bivalve veligers, gastropod veligers, and larval anthozoans) were at times concentrated on aggregates (Table 3 ). It should be noted that in most cases the percentages of the different types of plankton associated with the aggregates were generally low (Figs. 1 to 3). Comparisons of the percentage of the various types of zooplankters found on aggregates (Figs. 1 to 3) with the percentage of the water column occupied by aggregates (Table 1) suggests, however, that zooplankters were from 10 to $>1000 \times$ more concentrated on aggregates than in the surrounding aggregate-free water. Many of the enumerated zooplankters were not distributed randomly in the water column but tended to be concentrated significantly in a small fraction of the water column, namely the aggregates.

Several previous studies have presented evidence suggesting that metazoans reside on aggregates. Alldredge $(1972,1976)$, working in the Florida Current and the Gulf of California, found a variety of crustaceans residing on abandoned larvacean houses, one source of marine snow. She found that between 11 and $28 \%$ of the larvacean house aggregates were inhabited by crustaceans. The crustaceans found associated with aggregates included calanoid and cyclopoid copepods, ostracods, larval euphausids, and, occasionally, larval shrimps. Shanks \& Edmondson (1990) collected marine snow in the coastal waters off North Carolina and found a variety of metazoans associated with aggregates. Of the metazoans enumerated, holoplankters (e.g. calanoid and cyclopoid copepods, copepod nauplii, and larvaceans) were associated weakly with aggregates, with between 1 and $2 \%$ found on aggregates. In contrast, 15 and $83 \%$ of the harpacticoid copepods and nematodes, respectively, found in the water column were on aggregates. L.arval polychaetes also were associated strongly with aggregates. Bochdansky \& Herndl (1992) studied the association of zooplankton with aggregates collected in the northern Adriatic Sea. They found that several of the enumerated holoplanktonic crustaceans (e.g. Evadne sp., Podon sp., Acartia clausi) were associated weakly with aggregates, while copepod nauplii, harpacticoid copepods, larval polychaetes, juvenile turbellarians and the calanoid copepod Temora stylifera were associated more strongly with aggregates. Larvaceans, larval echinoderms, and veligers were present on aggregates, but accounted for $<10 \%$ of the aggregate-associated metazoans. Most recently, Green \& Dagg (1997) found a variety of metazoans concentrated on aggregates collected in the Gulf of Mexico.

Results from previous studies parallel findings in our present study. To date, the association of zooplankton with marine snow has been investigated at 3 locations in the Atlantic Ocean along the east coast of North America, at 2 coastal sites in the Eastern North Pacific, at a site in the Gulf of California, at a coastal site in the northern Adriatic Sea, and along a transect across the continental shelf in the Gulf of Mexico (this study and Alldredge 1972, 1976, Shanks \& Edmondson 1990, Bochdansky \& Herndl 1992, Green \& Dagg 1997). Given similar conclusions and the geographic range of the studies it is reasonable to conclude that in temperate coastal waters a variety of zooplankton, particularly meiofauna suspended in the water column and diverse larval forms, are associated with aggregates.

Two factors may have led to an underestimation of zooplankton-aggregate associations in this study. Field sampling was limited to aggregates larger than $1 \mathrm{~mm}$ in diameter and at all study sites numerous aggregates $<1 \mathrm{~mm}$ were present. During the observations of zooplankton in the vertical flume, zooplankters (e.g. copepod nauplii, nematodes, and larval polychaetes) were observed to associate with aggregates $<1 \mathrm{~mm}$ in diameter and likely associate with these smaller aggregates in the field. If this is indeed the case, then we have underestimated the actual degree of association of zooplankton with aggregates. Copepods have a strong escape response to turbulence and capturing aggregates by syringe sampling creates turbulence. Copepods occasionally were seen jumping off aggregates as they were being sampled. The sampling technique used by Green \& Dagg (1997) created less turbulence and they tended to find a higher number of copepods on aggregates than we observed. Both our sampling of only the larger aggregates and the escape behavior of aggregate-associated zooplankton. may have led to an 
underestimation of the degree of association of zooplankton with aggregates.

How do organisms become associated with aggregates? Given the abundance of marine snow, it seems inevitable that individual zooplankters will contact aggregates repeatedly. Zooplankton could actively avoid, actively associate, or passively become entangled with aggregates. Laboratory observations indicate that some crustaceans (e.g. calanoid copepods) actively avoided marine snow; they appeared to blunder into aggregates and then swim away. Other organisms (e.g. copepod nauplii, larval polychaetes, and, perhaps, harpacticoid copepods) appeared to visit aggregates (see also Shanks \& del Carmen 1997). Upon contacting an aggregate these organisms swam into the interstitial spaces of the aggregate or crawled across its surface. Only 1 of 4 nematodes observed left an aggregate and that appeared to be a consequence of the characteristic thrashing behavior of nematodes in aggregates. All of the other nematodes resided in the aggregates throughout the period of observation (up to $10 \mathrm{~min}$ ), and by their thrashing behavior appeared to add material to the aggregate. The association or lack of association between organisms and aggregates was active in all cases. Further, except for nematodes, our observations suggest that organisms which associate with marine snow may not be residing on the aggregate, but rather visiting aggregates for several minutes and then swimming away. From behavioral observations Alldredge (1972) came to a similar conclusion; copepods feeding on abandoned larvacean houses visited the houses, but spent only $4.6 \%$ of their time actually on the houses.

Holoplankters tended to be associated less with aggregates than were either meiofauna or some types of meroplankton (Figs. 1 to 3). The percent association with aggregates was as low as $0.1 \%$ for copepods and as high as $88 \%$ for nematodes. If we assume that zooplankton (other than nematodes) visit rather than reside on aggregates and that each visit is 3 min long (the average amount of time organisms were observed to reside on aggregates during the vertical flume observations), then the percentage of a population found on aggregates can be used to estimate the average amount of time a type of organism spends on aggregates and the number of aggregates visited over $24 \mathrm{~h}$ (Table 4). Cope-

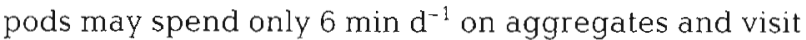
fewer than 2 aggregates. In contrast, nematodes and foraminiferans may spend more than half the day on aggregates. Copepod nauplii, harpacticoid copepods, bivalve and gastropod veligers, and larval anthozoans all spend greater than $1 \mathrm{~h} \mathrm{~d}^{-1}$ on aggregates and may visit from 20 to 60 aggregates each day (Table 4). These calculations suggest that marine snow may be playing an important role in the lives of some zooplankters.
Table 4. Average percentage of various populations of zooplankters found to associate with marine snow at a given tume and estimation of the number of hours $\mathrm{d}^{-1}$ zooplankters would spend on aggregates and the number of aggregates they would visit per day assuming each visit is only 3 min long

\begin{tabular}{|lccc|}
\hline Organism & \% Population & $\begin{array}{c}\text { Hours } \\
\mathrm{d}^{-1}\end{array}$ & $\begin{array}{c}\text { Aggregates } \\
\mathrm{d}^{-1}\end{array}$ \\
\hline $\begin{array}{l}\text { Larvaceans } \\
\text { Calanold/cyclopoid }\end{array}$ & 2.6 & 1 & 12 \\
$\quad$ copepods & 0.4 & 0.1 & 2 \\
Nauplii & 4.8 & 1 & 23 \\
Harpacticoids & 12.4 & 3 & 59 \\
Nematodes & 69.9 & 17 & 336 \\
Foraminiferans & 47.2 & 11 & 227 \\
Bivalves veligers & 5.8 & 1 & 28 \\
Gastropod veligers & 9.4 & 2 & 45 \\
Larval anthozoans & 13.5 & 3 & 65 \\
\hline
\end{tabular}

The most likely explanation for why zooplankton visit aggregates is to forage on the concentration of detritus and microbes (phytoplankton, bacteria, and protozoans) that are characteristic components of marine snow (Alldredge \& Silver 1988). Microbial populations on aggregates are at least $10 \times$ and frequently $1000 \times$ more concentrated in aggregates than in the surrounding water (Silver et al. 1978, Caron et al. 1983, Alldredge \& Youngbluth 1985, Beers et al. 1986, Davoll \& Silver 1986, Alldredge \& Silver 1988). The increased concentrations of microbes in aggregates suggests that aggregates are a food resource exploited by marine organisms. Several studies have presented evidence suggesting that holoplankters feed on aggregates (Alldredge 1972, 1976, Silver et al. 1978, Lampitt 1985, Suh et al. 1991, Larson \& Shanks 1996) and results from Walters \& Shanks (1996) suggest that harpacticoid copepods also are feeding on marine snow.

Marine snow is a decomposer community (Davoll \& Silver 1986) and consumption of marine snow by zooplankton should increase the rate at which detritus is recycled. Thus, it may increase the ecological efficiency of the pelagic community by cycling the energy trapped in the decomposing material back into the food web. The microbes composing the decomposer community are at higher concentrations within marine snow than in the surrounding water (Caron et al. 1983, Davoll \& Silver 1986, Alldredge \& Silver 1988). Feeding on these microbes may be more efficient because of the high concentrations. Further, microbes which are normally too small to be consumed by metazoan zooplankton (e.g. bacteria) may, when part of an aggregate, become available prey. Consumption of the bacterial component of marine snow may be an important supplement to the diet of those zooplankters which visit marine snow. 
Dissolved organic carbon in aggregates also might be a source of nutrition for zooplankton visiting aggregates. Intense hydrolytic activity of enzymes in aggregates (apparently released by aggregate-associated bacteria) solubilize the detrital component of marine snow (Smith et al. 1992). The complex mucous and particulate matrix of marine snow appears to retard diffusion rates of chemicals into or out of aggregates (Shanks \& Trent 1979, Alldredge \& Cohen 1987, Alldredge \& Silver 1988, Shanks \& Reeder 1993). Slow diffusion rates coupled with the rapid solubilization of particulate amino acids should lead to the build up of dissolved amino acids within aggregates. There is increasing evidence that some types of larval invertebrates (e.g. larval echinoderms, gastropods, and bivalves) may supplement their nutritional needs by the uptake of dissolved amino acids (reviewed in Boidron-Metairon 1995). Perhaps larvae and other zooplankters visiting aggregates are exploiting increased concentrations of dissolved organic matter within aggregates as a source of nutrition.

The local concentrations of larger phytoplankton and zooplankton (e.g. diatoms, dinoflagellates, and the zooplankton enumerated in this study) often are much greater in marine snow than in the surrounding waters (Silver et al. 1978, Beers et al. 1986, Alldredge \& Silver 1988, Shanks \& Edmondson 1990, Bochdansky \& Herndl 1992). Organisms that feed on these phytoplankton and zooplankton may thus search preferentially for food in aggregates. For example, larval magelonid and spionid polychaetes that prey on bivalve veligers (Lebour 1922, Daro 1978, Wilson 1982) are amongst the larval polychaetes which visit aggregates (Shanks \& Edmondson 1990). Perhaps predation on bivalves by these polychaetes occurs during visits to marine snow where numbers of their prey are one to several orders of magnitude more concentrated than in the surrounding waters. As an additional example, the dinoflagellate Noctiluca sp. feeds primarily on diatoms (LeFevre \& Grall 1970), and in the samples collected from West Sound Noctiluca scintillans was concentrated in aggregates (Shanks \& Walters 1996). Most of the feeding by $N$. scintillans occurred within aggregates (Shanks \& Walters 1996). Diatoms were the principal prey of aggregate-associated $N$. scintillans but anthozoan larvae that were concentrated in marine snow also were consumed (Fig. 3). Thus, because of the increased concentration of potential prey items some types of organisms may forage preferentially within aggregates.

Nematodes and foraminifera were the organisms most strongly associated with aggregates (Table 4). Shanks \& Edmondson (1990) also found a strong association of nematodes with aggregates. The behavioral observations reported here suggest that nematodes reside in aggregates and actually collect material from the surrounding water and add it to aggregates. The fluff layer often found on the sediment surface is similar in appearance and structure to marine snow and may be composed of marine snow that has settled to the bottom (Lampitt 1985). Nematodes and foraminifera encountering marine snow in the water column may simply perceive aggregates as the benthos. A potential advantage to meiofauna-marine snow associations is that in most situations marine snow sinks through the water column (Asper 1986, Alldredge \& Gotschalk 1988, Riebesell 1989, Shanks \& Edmondson 1990; however, see Riebesell 1989, Herndl 1992); thus much of the vertical flux of material through the water column results from marine snow (Shanks \& Trent 1980, Asper 1986, Alldredge \& Gotschalk 1988, Riemann 1989, Walsh \& Gardner 1992, Syvitski et al. 1995). Meiofauna on sinking aggregates will be transportcd passively toward the bottom and eventually will be deposited on the bottom with the aggregate. In fact, Shanks \& Edmondson (1990) found that most of the vertical flux of nematodes resulted from individuals on aggregates. Meiofauna on aggregates will sink through the water column as passive particles and, on the fine scale (sensu Eckman 1975), be deposited on the bottom in patterns controlled by the physics of marine snow deposition.

Two decades of research have demonstrated that aggregates are ubiquitous in the ocean (Alldredge \& Silver 1988) and also are present in lakes (Grossart \& Simon 1993). In a cubic meter of water there may be anywhere from $10^{3}$ to $10^{5}$ aggregates (Alldredge \& Silver 1988). Given the sinking rate of aggregates (Shanks \& Trent 1980, Asper 1986, Alldredge \& Gotschalk 1988), the flux of marine snow through a square meter of water may be on the order of $10^{5}$ to $10^{6}$ aggregates $\mathrm{m}^{-2} \mathrm{~d}^{-1}$ (Shanks \& Edmondson 1990). Numerous studies (this study and Alldredge 1972, Alldredge 1976, Shanks \& Edmondson 1990, Bochdansky \& Herndl 1992, Green \& Dagg 1997) suggest that some types of metazoans actively associate with marine snow. The broad geographic range of these observations indicates that metazoan-marine snow associations are common occurrences in the coastal waters of the world's oceans. Some types of organisms, e.g nematodes or foraminiferians suspended in the water column, are inhabitants of aggregates and nearly all of the population will be found in aggregates. A variety of other metazoans, meroplankton and holoplankton actively visit aggregates (this study and Alldredge 1972, 1976, Shanks \& Edmondson 1990, Bochdansky \& Herndl 1992, Green \& Dagg 1997). An individual copepod nauplii or bivalve veliger might visit 10 s of aggregates each day (Table 4), while a competent larval polychaete might visit several hundred (Shanks \& del 
Carmen 1997). Like bees visiting flowers, these zooplankters may be swimming from aggregate to aggregate. These visits probably are for the purpose of feeding on the concentrated microbial community characteristic of aggregates. That some types of zooplankton visit marine snow is clear; the role these visits play in their ecology is unknown.

Acknowledgements. This research was supported by NSF Grant OCE9017807 Field or laboratory assistance was provided by G. Reikerk, M. Williams, M. Reeder, E. Larson, and R. Hooff. Helpful comments on the manuscript were provided by L. Brink and R. Hooff. Field work in the San Juan Islands was greatly facilitated by the help of the faculty and staff of the Friday Harbor Laboratories, University of Washington. This is a contribution from the Oregon Institute of Marine Biology, the University of Oregon.

\section{LITERATURE CITED}

Alldredge AL (1972) Abandoned larvacean houses: a unique food source in the pelagic enviornment. Science 177 : $885-887$

Alldredge AL (1976) Discarded appendicularian houses as sources of food, surface habitats, and particulate organic matter in planktonic environments. Limnol Oceanogr 21: $14-23$

Alldredge AL, Cohen Y (1987) Can microscale chemical patches persist in the sea? Microelectrode study of marine snow, fecal pellets. Science 235:689-691

Alldredge A.L, Gotschalk C (1988) In situ settling behavior of marine snow. Limnol Oceanogr 33:339-351

Alldredge AL, Silver MW (1988) Characteristics, dynamics and significance of marine snow. Prog Oceaogr 20:41-82

Alldredge AL, Youngbluth MJ (1985) The significance of macroscopic aggregates (marine snow) as sites for heterotrophic bacterial production in the mesopelagic zone of the subtropical Atlantic. Deep Sea Res 32:1445-1456

Asper $V$ (1986) Measuring the flux and sinking speed of marine snow aggregates. Deep Sea Res 34:1-18

Beers JR, Trent JD, Reid FMH, Shanks AL (1986) Macroaggregates and their phytoplanktonic components in the Southern California Bight. J Plankton Res 8:475-487

Bochdansky AB, Herndl GJ (1992) Ecology of amorphous aggregations (marine snow) in the Northern Adriatic Sea. III. Zooplankton interactions with marine snow. Mar Ecol Prog Ser 87:135-146

Boidron-Metairon IF (1995) Larval nutrition. In: McEdward L (ed) Ecology of marine invertebrate larvae. CRC, Boca Raton, p 223-248

Caron DA, Davis PG, Madin LP, Sieburth JM (1983) Heterotrophic bacteria and bacterivorous protozoa in oceanic macroaggregates. Science 318:795-797

Caron DA, Davis PG, Madin LP, Sieburth JM (1986) Enrichment of microbial populations in macroaggregates (marine snow) from surface waters of the North Atlantic. J Mar Res 44:543-565

Daro $\mathrm{MH}$ (1978) A simplified $14 \mathrm{C}$ method for grazing measurments on natural planktonic populations. Helgol Wiss Meeresunters 31:241-248

Davoll PJ, Silver MW (1986) Marine snow aggregates: life history sequence and microbial community of abandoned larvacean houses from Monterey Bay, California. Mar Ecol Prog Ser 33:111-120
Eckman JE (1975) Small-scale patterns and processes in a soft-substratum, intertidal community. J Mar Res 37 : $437-457$

Green EP, Dagg MJ (1997) Mesozooplankton associations with medium to large marine snow aggregates in the northern Gulf of Mexico. J Plankton Res 19:435-447

Grossart HP, Simon M (1993) Limnetic macroscopic organic aggregates (lake snow): Occurrence, characteristics, and microbial dynamics in Lake Constance. Limnol Oceanogr $38: 532-546$

Herndl GJ (1992) Marine snow in the Northern Adriatic Sea: Possible causes and consequences for a shallow ecosystem. Mar Nicrob Food Webs 6:149-172

Honjo S, Doherty KW, Agrawal YC, Asper VL (1984) Direct optical assessment of large amorphous aggregates (marine snow) in the deep ocean. Deep Sea Res 31:67-76

Hyman LH (1940) The invertebrates: protozoa through ctenophora. McGraw-Hill Book Co, New York

Joyner SP (1985) SAS/STAT guide for personal computers SAS Institue Inc, Cary, NC

Lampitt RS (1985) Evidence for the seasonal deposition of detritus for the deep-sea floor and its subsequent resuspension. Deep Sea Res 32:885-897

Larson ET, Shanks AL (1996) Consumption of marine snow by two species of juvenile mullet and its contribution to their growth. Mar Ecol Prog Ser 130:19-28

Lebour MV (1922) The food of planktonic organisms. J Mar Biol Assoc UK 12:644-677

LeFevre J, Grall JR (1970) On the relationship of Noctiluca swarming off the western coast of Brittany with hydrological features and plankton characteristics of the environment. J Exp Mar Biol Ecol 4:287-306

LeLoup E (1962) Anthozoa Ceriantharia: larvae. Cons Int Explor Mer Zooplankton Sheet 93:1-7

Lochte K, Turley CM (1988) Bacterial and cyanobacteria associated with phytodetritus in the deep sea. Nature 333:67-69

Omori M, Ikeda $T$ (1984) Methods in marine zooplankton ecology. John Wiley \& Sons, New York

Riebesell U (1989) Comparison of sinking and sedimentation rate measurements in a diatom winter/spring bloom. Mar Ecol Prog Ser 54:109-119

Riemann F (1989) Gelatinous phytoplankton detritus aggregates on the Atlantic deep-sea bed Structure and mode of formation. Mar Biol 100:533-539

Shanks AL, del Carmen KA (1997) Larval polychaetes are strongly associated with marine snow. Mar Ecol Prog Ser $154: 211-221$

Shanks AL, Edmondson EW (1989) Laboratory-made marine snow: a biological model of the real thing. Mar Biol 101: 463-470

Shanks AL, Edmondson EW (1990) Vertical flux of metazoans (holoplankton, melofauna, and larval invertebrates) due to their association with marme snow. Limnol Oceanogr 35: $455-463$

Shanks AL, Reeder M (1993) Reducing microzones and sulfide production in marine snow. Mar Ecol Prog Ser 96: 43-47

Shanks AL, Trent JD (1979) Marine snow: microscale nutrient patches. Limnol Oceanogr 24:850-854

Shanks AL, Trent JD (1980) Marine snow: sinking rates and potential role in vertical flux. Deep Sea Res 27:137-144

Shanks AL, Walters K (1996) Feeding by a heterotrophic dinoflagellate (Noctiluca scintillans) in marine snow. Limnol Oceanogr 41:171-181

Silver MW, Shanks AL, Trent JD (1978) Marine snow: microplankton habitat and source of small-scale patchiness in pelagic populations. Science 201:371-373 
Simon M. Alldredge AL, Azam F (1990) Bacterial carbon dynamics on marine snow. Mar Ecol Prog Ser 65: 205-21.1

Smith DC, Simon M. Alldredge AL, Azam F (1992) Intense hydrolytic enzyme activity on marine aggregates and implications for rapid particle dissolution. Nature 359: $139-142$

Suh HL, Toda T, Terazakı M (1991) Diet of calyptopes of the euphausid Euphausia pacifica in the Yellow Sea. Mar Biol $111: 45-48$

Syvitski JPM, Asprey KW, Leblanc KWG (1995) In situ char-

This article was submitted to the editor acteristics of particles settling withın a deep-water estuary. Deep Sea Res 42:223-256

Walsh ID, Gardner WD (1992) A comparison of aggregate profiles with sediment trap fluxes. Deep Sea Res 39: $1817-1834$

Walters K, Shanks AL (1996) Complex trophic and nontrophic interactions between meiobenthic copepods and manne snow. J Exp Mar Biol Ecol 198:131-145

Wilson DP (1982) The larval development of three species of Magelona (Polychaeta) from the localities near Plymouth. J Mar Biol Assoc UK 62:385-401

Manuscript received: April 16, 1997

Revised version accepted: June 10, 1997 